\title{
Väkirehuna käytetyn viljalajin (ohra vs. kaura) sekä valkuaislisän tuotan- tovaikutukset maitorotuisten sonnien teuraskasvatuksessa
}

\author{
Arto Huuskonen ${ }^{1)}$ ja Sirpa Lunki ${ }^{2)}$ \\ ${ }^{1)}$ Maa- ja elintarviketalouden tutkimuskeskus, Kotieläintuotannon tutkimus, Halolantie 31A, 71750 \\ Maaninka,arto.huuskonen@mtt.fi \\ 2) Maa- ja elintarviketalouden tutkimuskeskus, Kotieläintuotannon tutkimus, Tutkimusasemantie 15, \\ 92400 Ruukki,sirpa.lunki@mtt.fi
}

\section{Tiivistelmä}

Kokeen tarkoituksena oli selvittää ohran korvaamista kauralla maitorotuisten sonnien väkirehuruokinnassa. Lisäksi tutkittiin valkuaislisän vaikutusta sonnien kasvuun. Ruokintakokeessa oli mukana 60 maitorotuista sonnia. Sonnit ruokittiin erillisruokinnalla siten, että kaikki eläimet saivat vapaasti hyvälaatuista nurmisäilörehua (D-arvo 69, raakavalkuaispitoisuus $16 \%$, säilönnällinen laatu hyvä). Viljaruokintoja oli kolme erilaista. Ensimmäinen koeryhmä sai väkirehuna litistettyä ohraa. Toisen ryhmän väkirehuna oli ohran ja kauran seos, jossa oli puolet kumpaakin viljalajia. Kolmannen koeryhmän viljaväkirehuna oli litistetty kaura. Tämän lisäksi kaikki eläimet saivat tarpeelliset kivennäis- ja vitamiinilisäykset. Puolet koesonneista sai kullakin viljaväkirehuruokinnalla valkuaislisänä melassoitua rypsiä ja puolet kasvoi ilman valkuaislisää. Kokeessa oli siis kaksi tutkittavaa tekijää: viljaväkirehu ja valkuaisrehu. Väkirehun annostelumäärä oli kaikissa ruokintaryhmissä $37 \mathrm{~g}$ eläimen metabolista elopainokilogrammaa kohti, mikä tarkoitti käytännössä sitä, että ruokinnan väkirehuprosentiksi muodostui 40 \%. Tällöin eläimen saama väkirehumäärä oli kokeen alussa (250-300 kg:n elopainossa) noin 3 kg päivässä ja kokeen lopussa (600-650 kg:n elopainossa) noin 5,2 kg päivässä. Sonnit olivat kokeen alussa 6,5 kuukauden ikäisiä ja painoivat keskimäärin 258 kilogrammaa. Kokeen lopussa eläinten keskimääräinen elopaino oli $686 \mathrm{~kg}$ ja teuraspaino $354 \mathrm{~kg}$. Sonnien keskimääräinen nettokasvu koko koeajalla oli 652 g/pv. Kasvutulokset heikkenivät hieman, kun ohraa korvattiin kauralla. Tämä johtui todennäköisesti kauran hieman ohraa suuremmasta kuitupitoisuudesta ja sen myötä heikommasta rehuarvosta, minkä seurauksena sonnien energian saanti väheni hieman korvattaessa ohraa kauralla. Ohran hehtolitrapaino kokeen aikana oli keskimäärin $62 \mathrm{~kg}$ ja kauran $58 \mathrm{~kg}$. Teurastuloksiin väkirehuruokinnoilla ei ollut vaikutusta. Keskimääräinen lihakkuusluokka oli kokeen sonneilla $\mathrm{O}$ - ja rasvaisuusluokka 2,9. Tutkimustulosten perusteella ohran korvaaminen kauralla näyttää heikentävän hieman sonnien kasvua erillisruokinnalla. Naudanlihantuottajan kannalta kauran käyttö ruokinnassa voi kuitenkin muodostua taloudellisesti järkeväksi, jos sen hinta suhteessa tuotantovaikutukseen on edullisempi kuin ohralla. Rypsilisä ei ole kokeissa vaikuttanut lainkaan eläinten tuotantotuloksiin. Sonnien rehun syönti, kasvu ja teurastulokset olivat samalla tasolla riippumatta siitä, saivatko eläimet rypsilisän vai eivät. Valkuainen on suhteellisen kallis rehukomponentti, jonka pois jättämisellä on mahdollisuus säästää ruokintakustannuksissa niissä tapauksissa, joissa valkuaislisällä ei saada tuotosvastetta. Tässä kokeessa rypsilisäys oli sonnia kohti keskimäärin $0,5 \mathrm{~kg}$ päivässä noin vuoden ajan. Tällöin rypsiä kului sonnia kohti 182,5 kg. Rypsin energia-arvo on hieman rehuohraa matalampi, joten edellä mainitun rypsimäärän energiasisällön korvaamiseen tarvitaan noin $159 \mathrm{~kg}$ rehuohraa. Rehuohran arvonlisäveroton hinta kirjoitushetkellä on noin 80 euroa/tonni ilman rahtikustannusta ja rypsin vastaava hinta noin 215 euroa/tonni. Näillä rehun hintaeroilla rypsilisän pois jättämisestä aiheutuva säästö on 26,52 euroa sonnia kohti kasvatuskauden aikana. Summa ei ole sinänsä kovin suuri yhden sonnin tapauksessa, mutta tuhannella sonnilla säästöä kertyy jo 26520 euroa ja teuraspainokilogrammaa kohden $7,4-7,8$ senttiä.

Asiasanat: naudanlihantuotanto, sonnit, ruokinta, väkirehut, ohra, kaura, valkuainen 


\section{Johdanto}

Maa- ja elintarviketalouden tutkimuskeskuksen (MTT) koordinoimassa "Vilja rehuksi suoraan tiloilla" -hankkeessa selvitettiin ohran korvaamista kauralla maitorotuisten sonnien väkirehuruokinnassa. Lisäksi tutkittiin valkuaislisän vaikutusta sonnien kasvuun. Hanketta rahoittivat Pohjois-Pohjanmaan TE-keskus EMOTR-ohjelman kautta, MTT, TTS-tutkimus, Melica Oy ja Altia Oyj.

\section{Aineisto ja menetelmät}

Maitorotuisten sonnien ruokintatutkimus toteutettiin MTT:n Ruukin toimipisteessä kahtena erillisenä ruokintakokeena (koe 1 ja koe 2). Ensimmäinen koe alkoi huhtikuussa 2006 ja toinen koe joulukuussa 2006. Ensimmäisessä kokeessa oli 18 ay-sonnia ja 12 holstein-friisiläis-sonnia. Toisessa kokeessa oli vastaavasti 24 ay-sonnia 6 holstein-friisiläis-sonnia. Kokeen alkaessa eläimet siirrettiin vasikkakasvatustiloista parsinavettaan, jossa ne kytkettiin parteen. Järjestelyllä saatiin eläinkohtaisia havaintoja. Kokeen alkaessa sonnien keskimääräinen elopaino oli $257 \pm 26,6 \mathrm{~kg}$, ja ne olivat keskimäärin 6,5 kuukauden ikäisiä. Molempien kokeiden alussa eläimet ryhmiteltiin elopainon ja rodun perusteella viiteen blokkiin, joista ne sijoitettiin satunnaisesti kuudelle eri koeruokinnalle.

Vertailtavina koetekijöinä olivat väkirehuna käytetty viljalaji ja ruokinnan valkuaisrehutäydennys. Käytetyt kolme viljaväkirehua olivat 1) litistetty ohra, 2) litistetty ohra + litistetty kaura (50:50) ja 3) litistetty kaura. Kullakin viljaväkirehuruokinnalla eläimet oli jaettu kahdelle eri valkuaisruokinnalle. Valkuaisrehuruokinnan vertailtavana koetekijänä oli rypsilisäys: sonnit saivat väkirehuna joko pelkkää rehuviljaa tai rehuviljan ja rypsin seosta. Rypsilisällä väkirehun raakavalkuaispitoisuus nostettiin 16 prosenttiin. Näin ollen rypsilisän määrä riippui perusväkirehun eli rehuviljan valkuaispitoisuudesta, jota seurattiin rehuanalyyseillä. Keskimäärin rypsilisäys oli $440 \mathrm{~g}$ kuiva-ainetta eläintä kohti päivässä.

Sonnit ruokittiin erillisruokinnalla ja ne saivat vapaasti hyvälaatuista nurmisäilörehua. Tarjottu väkirehumäärä oli 37 grammaa eläimen metabolista elopainokilogrammaa kohden päivässä, jolloin ruokinnan väkirehuprosentiksi muodostui $40 \%$. Ruokinnassa huolehdittiin myös eläinten kivennäisaineiden sekä vitamiinien tarpeesta.

Rehujen kemiallinen koostumus määritettiin Ahvenjärven (2000) kuvailemalla tavalla. Säilörehusta määritettiin lisäksi käymislaatu (pH, kokonaistyppi, liukoinen typpi, ammoniumtyppi, haihtuvat rasvahapot ja maito- sekä muurahaishappo) puristenestetitraukseen pohjautuvalla laatumäärityksellä (Moisio ja Heikonen 1989). Säilörehun D-arvo määritettiin NIR-menetelmällä (Nousiainen ym. 2004). Rehujen energia- ja valkuaisarvot laskettiin MTT:n (2006) kuvaamalla tavalla.

Tulosten tilastollinen käsittely tehtiin SAS-ohjelmiston varianssianalyysillä. Testauksen koemalli oli lohkoittain satunnaistettu koe. Koemalli: $\left.\mathrm{y}_{\mathrm{ijkl}}=\mu+\mathrm{koe}_{\mathrm{k}}+\operatorname{lohko(koe)}\right)_{\mathrm{kl}}+$ viljaväkirehu $_{\mathrm{i}}+$

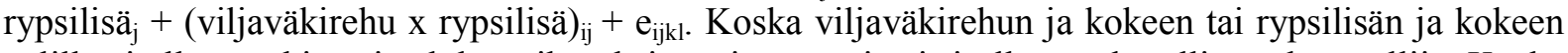
välillä ei ollut merkitseviä yhdysvaikutuksia, näitä termejä ei sisällytetty lopulliseen koemalliin. Koska viljaväkirehun ja rypsilisän välillä ei ollut tilastollisesti merkitseviä yhdysvaikutuksia $(\mathrm{p}>0.05)$, tulokset on esitetty koetekijöittäin.

\section{Tulokset ja tulosten tarkastelu}

Säilörehun säilönnällinen laatu oli kokeen aikana hyvä käymishappojen pitoisuuden sekä ammoniumja liukoisen typen osuuksien perusteella mitattuna (Taulukko 1). Säilörehun D-arvo oli keskimäärin 69 koesarjan aikana. Kokeessa käytetyn ohran energia-arvo oli $7 \%$ kauran energia-arvoa korkeampi, mutta kaura sisälsi $5 \%$ enemmän raakavalkuaista kuin ohra. Kauran OIV-arvo oli $6 \%$ matalampi ja NDF-pitoisuus $30 \%$ korkeampi kuin ohralla. Kaura sisälsi $27 \%$ vähemmän tärkkelystä kuin ohra. Kokeessa käytetty rypsi sisälsi selvästi enemmän fosforia kuin nurmisäilörehu, ohra ja kaura (Taulukko 1). Sonnien elopaino kokeen alussa oli keskimäärin $257 \mathrm{~kg}$ ja kokeen päättyessä keskimäärin 687 $\mathrm{kg}$ (Taulukko 2).

\section{Viljalajin vaikutus}

Ohra korvaaminen kauralla heikensi dieetin kuiva-aineen, orgaanisen aineen ja kuidun sulavuutta (Taulukko 4). Kaura sisältää enemmän kuitua ja vähemmän tärkkelystä kuin ohra, ja erot kuiva-aineen ja orgaanisen aineen sulavuudessa johtunevat suurelta osin näistä eroista kemiallisessa koostumuksessa. Vastaavia dieetin näennäisen sulavuuden heikkenemisiä on havaittu, kun ohraväkirehua on korvat- 
tu kuitupitoisella ohrarehulla, jota syntyy integroidun tärkkelys-etanoliteollisuuden sivutuotteena (Huuskonen ym. 2007 a, 2008a).

Ohran korvaaminen kauralla heikensi sonnien päiväkasvua noin 100 grammaa (Taulukko 2). Tämä johtui todennäköisesti kauran ohraa suuremmasta kuitupitoisuudesta ja sen myötä heikommasta rehuarvosta, minkä seurauksena sonnien energian saanti väheni korvattaessa ohraa kauralla. Koska kuiva-aineen syöntimäärissä ei ollut merkitseviä eroja viljalajien välillä, rehun hyväksikäyttö kasvuun heikkeni korvattaessa ohraa kauralla. Tämän tutkimuksen tulokset ovat ristiriidassa Corahin ym. (1975) ja Dionin ja Seoanen (1992) julkaisemien tulosten kanssa, joissa ei raportoitu eroja ohra- ja kauraväkirehulla ruokittujen härkien kasvu- ja rehun hyväksikäyttötuloksissa heinäpohjaisella ruokinnalla. Nämä erot tutkimusten välillä ovat todennäköisesti selitettävissä rehujen energiasisällön perusteella. Tässä tutkimuksessa ohran energia-arvo oli 7 \% suurempi kuin kauralla, mutta Dionin ja Seoanen kokeessa ohran ja kauran energia-arvot olivat samalla tasolla.

Tämän kokeen tulokset poikkeavat joistakin aikaisemmista sonneilla tehdyistä seosrehuruokintakokeista, joissa ohraväkirehua on osittain korvattu kuitupitoisemmalla väkirehulla. Esimerkiksi ohrarehulla tehdyissä seosrehukokeissa ohran osittainen korvaaminen ohrarehulla on lisännyt sonnien rehun syöntiä (Huuskonen ym. 2007a, 2008a). Tällöin ohrarehuseosta saaneet sonnit ovat pystyneet kompensoimaan seoksen hieman heikompaa energia-arvoa syöntiä lisäämällä. Tällainen energeettinen syönnin säätely on naudalla periaatteessa mahdollista siihen saakka, kunnes pötsin täyteisyys muodostuu rajoittavaksi tekijäksi (Forbes 2007). Tässä kokeessa sonnit ruokittiin erillisruokinnalla ja väkirehun määrä oli rajoitettu. Tällöin eläinten olisi pitänyt lisätä nurmisäilörehun syöntiä, jotta kauran ohraa heikompi energia-arvo olisi tullut kompensoitua. Tätä lisäystä säilörehun syönnissä ei kuitenkaan tapahtunut, jolloin kasvu jäi hieman heikommaksi korvattaessa ohraa kauralla. Sen sijaan teurastuloksiin väkirehuruokinnoilla ei ollut vaikutusta. Keskimääräinen lihakkuusluokka oli kokeen sonneilla O- ja rasvaisuusluokka 2,9 (Taulukko 2)..

\section{Valkuaislisän vaikutus}

Rypsin lisääminen rehuannokseen paransi dieetin raakavalkuaisen sulavuutta, koska rypsillä raakavalkuaisen sulavuus on noin 10 prosenttiyksikkö parempi kuin ohralla (MTT 2006). Dieetin kuiva-aineen, orgaanisen aineen tai NDF-kuidun sulavuuteen rypsilisäyksellä ei ollut vaikutusta.

Rypsilisä ei tässä kokeessa vaikuttanut lainkaan eläinten tuotantotuloksiin (Taulukot 2 ja 4). Sonnien rehun syönti, kasvu ja teurastulokset olivat samalla tasolla riippumatta siitä, saivatko eläimet rypsilisän vai eivät. Tulokset tukevat aikaisempia maitorotuisten sonnien kasvatuskokeita, joissa valkuaislisällä ei ole saatu tuotosvastetta (Huuskonen ym. 2007b, 2008b). Joissakin vanhemmissa tutkimuksissa (esim. Aronen 1991, Aronen ja Vanhatalo 1992) rypsilisällä on raportoitu olleen positiivinen vaikutus lihanautojen kasvuun. Tätä on kyseisissä tutkimuksissa selitetty lisääntyneellä säilörehun syönnillä ja sitä kautta lisääntyneellä energian saannilla. Eräissä tutkimuksissa (Huhtanen ym. 1989, Aronen 1990) valkuaislisän positiivinen vaikutus kasvuun on rajoittunut ensimmäisiin ruokintajaksoihin (elopaino alle $300 \mathrm{~kg}$ ). Tämä selittyy sillä, että nuorella naudalla mikrobisynteesi ei yleensä riitä tyydyttämään nopean kasvun vaatimaa aminohappotarvetta. Elopainon noustessa rehun syönti kuitenkin lisääntyy ja kasvun koostumus muuttuu, jolloin mikrobisynteesin pitäisi ARC:n (1980) mukaan keskimäärin 250 elopainokilon jälkeen riittää tyydyttämään lihanaudan aminohappotarpeen. Myös tässä kokeessa elopainon vaikutus oli havaittavissa, sillä ensimmäisellä jaksolla rypsilisäyksellä oli positiivinen vaikutus eläinten kasvuun (Taulukko 3). Ensimmäisellä jaksolla saavutettu etu kuitenkin menetettiin kokeen aikana.

Valkuainen on suhteellisen kallis rehukomponentti, jonka pois jättämisellä on mahdollisuus säästää ruokintakustannuksissa niissä tapauksissa, joissa valkuaislisällä ei saada tuotosvastetta. Tässä kokeessa rypsilisäys oli sonnia kohti keskimäärin $0,5 \mathrm{~kg}$ päivässä noin vuoden ajan. Tällöin rypsiä kului sonnia kohti 182,5 kg. Rypsin energia-arvo on hieman rehuohraa matalampi, joten edellä mainitun rypsimäärän energiasisällön korvaamiseen tarvitaan noin $159 \mathrm{~kg}$ rehuohraa. Rehuohran arvonlisäveroton hinta kirjoitushetkellä on noin 80 euroa/tonni ilman rahtikustannusta ja rypsin vastaava hinta noin 215 euroa/tonni. Näillä rehun hintaeroilla rypsilisän pois jättämisestä aiheutuva säästö on 26,52 euroa sonnia kohti kasvatuskauden aikana. Summa ei ole sinänsä kovin suuri yhden sonnin tapauksessa, mutta tuhannella sonnilla säästöä kertyy jo 26520 euroa ja teuraspainokilogrammaa kohden $7,4-7,8$ senttiä. 


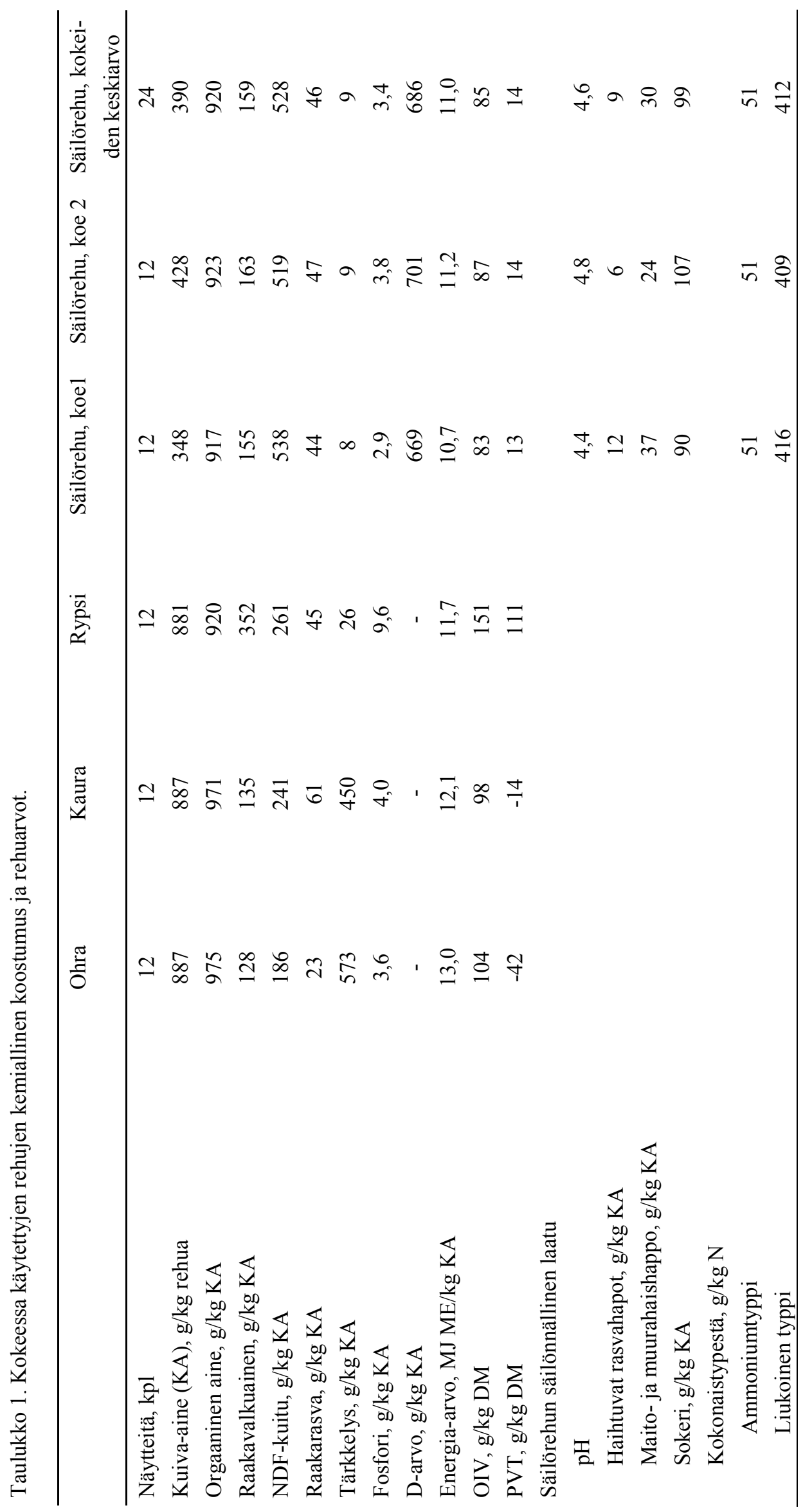









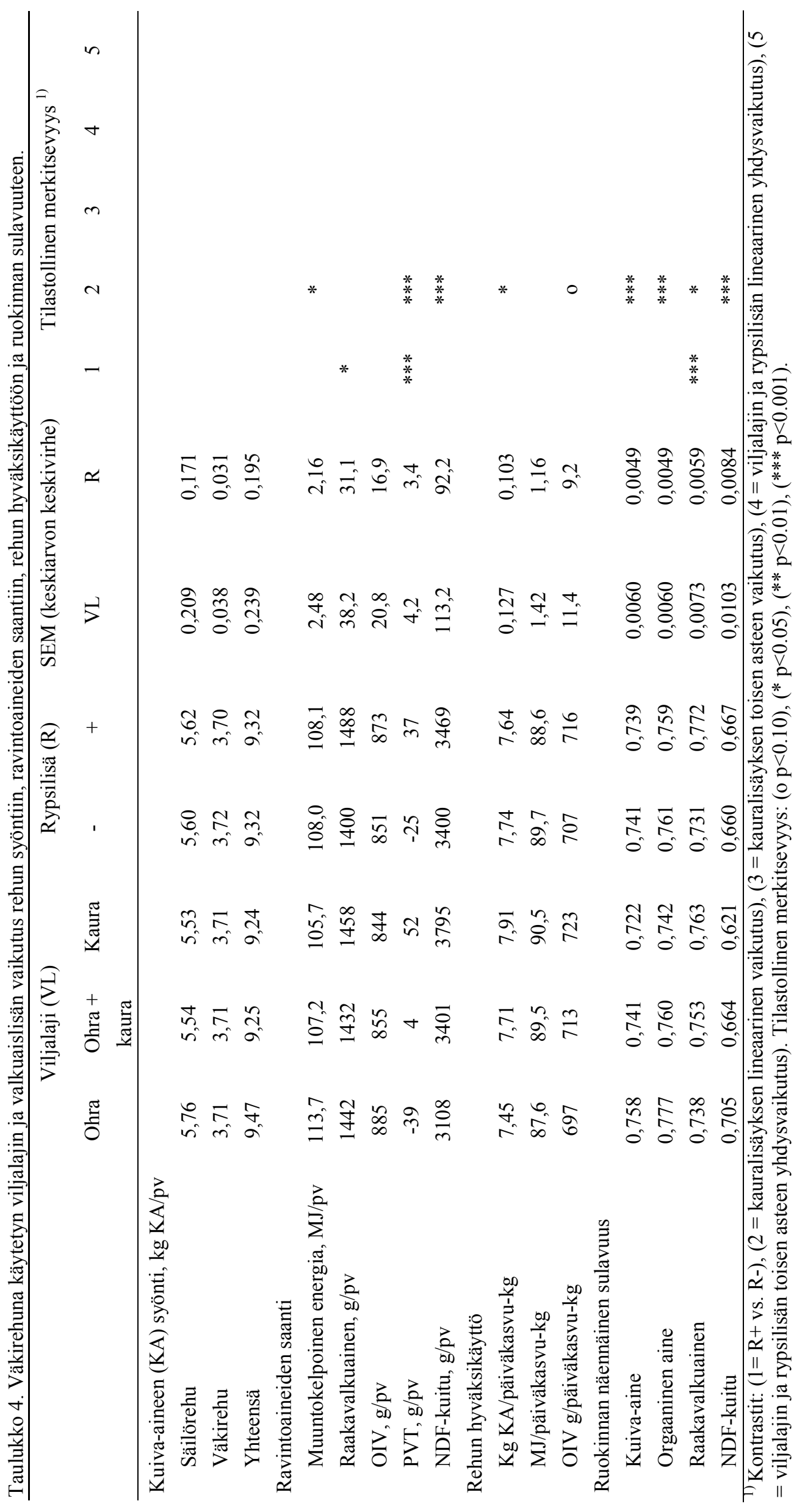




\section{Yhteenveto ja johtopäätökset}

Tulosten perusteella ohran korvaaminen kauralla näyttää heikentävän hieman sonnien kasvua erillisruokinnalla. Naudanlihantuottajan kannalta kauran käyttö ruokinnassa voi kuitenkin muodostua taloudellisesti järkeväksi, jos sen hinta suhteessa tuotantovaikutukseen on edullisempi kuin ohralla. Tämä tarkoittaa sitä, että ohran osittainen korvaaminen kauralla saattaa olla taloudellisesti järkevää, vaikka kasvutulokset ja rehun hyväksikäyttö hieman heikkenisivätkin. Valkuaislisän käytöllä ei saavuteta etua yli puolen vuoden ikäisten maitorotuisten sonnien ruokinnassa, jos karkearehuna käytetään hyvälaatuista, hyvin sulavaa nurmisäilörehua. Valkuaislisä on kallis rehu, jonka pois jättämisellä voi säästää ruokintakustannuksessa.

\section{Kirjallisuus}

Ahvenjärvi, S., Vanhatalo, A., Huhtanen, P. \& Varvikko, T. 2000. Determination of reticulo-rumen and stomach digestion in lactating cows by omasal canal and duodenal sampling. British J. Nutr. 83: 67-77.

ARC (Agricultural Research Council) 1980. The nutrient requirements of ruminant livestock. Commonwealth Agricultural Bureaux, Farnham Royal, Surrey, UK. 351 s.

Aronen, I. 1990. Barley protein and rapeseed meal as protein supplements for growing cattle. Acta Agric. Scand. 40: 297-307.

Aronen, I. 1991. Influence of frequency and accuracy of supplement feeding on rumen fermentation, feed intake, diet digestion and performance of growing cattle I. Studies with growing bulls fed grass silage ad libitum. Anim. Feed Sci. Technol. 34: 49-65.

Aronen, I. \& Vanhatalo, A. 1992. Heat-moisture treatment of rapeseed meal: effect on diet digestion, voluntary grass silage intake and growth of Ay-bulls. Acta Agric. Scand., Sect. A, Anim. Sci. 42: 157-166.

Corah, L.R., Jackson, S.A. \& Bishop, A.H. 1975. Growth and carcasse composition of yearling cattle fattened on combinations of hay, grain and NPN in a feedlot and on grain supplemented pastures. Aust. J. Exp. Agric. Anim. Husb. 15: 299-307.

Dion, S. \& Seoane, J.R. 1992. Nutritive value of corn, barley, wheat and oats fed with medium quality hay to fattening steers. Can. J. Anim. Sci. 72: 367-373.

Huhtanen, P., Näsi, M. \& Khalili, H. 1989. By-products from integrated starch-ethanol production from barley in the diets of growing cattle. J. Agric. Sci. Finl. 61: 451-462.

Huuskonen, A., Khalili, H. \& Joki-Tokola, E. 2007a. Effects of replacing different proportions of barley grain by barley fibre on performance of dairy bulls. Agric. Food Sci. 16: 232-244.

Huuskonen, A., Khalili, H. \& Joki-Tokola, E. 2007b. Effects of three different concentrate proportions and rapeseed meal supplement to grass silage on animal performance of dairy-breed bulls with TMR feeding. Livest. Sci. 110: 154-165.

Huuskonen, A., Khalili, H. \& Joki-Tokola, E. 2008a. Inclusion of barley fibre and barley protein in a total mixed ration for growing dairy bulls. Acta Agric. Scand., Sect. A, Anim. Sci. 58: 37-44.

Huuskonen, A., Khalili, H. \& Joki-Tokola, E. 2008b. Need for protein supplementation in the diet of growing dairy bulls fed total mixed ration based on moderate digestible grass silage and barley. Agric. Food Sci. 17: 109120.

Moisio, T. \& Heikonen, M. 1989. A titration method for silage assessment. Anim. Feed Sci. Technol. 22: 341353.

MTT 2006. Rehutaulukot ja ruokintasuositukset. Maa- ja elintarviketalouden tutkimuskeskus, Jokioinen. Julkaistu 14.2.2006, [viitattu 6.11.2009]. Saatavissa internetistä: http://www.agronet.fi/rehutaulukot/.

Nousiainen, J., Ahvenjärvi, S., Rinne, M., Hellämäki, M. \& Huhtanen, P. 2004. Prediction of indigestible cell wall fraction of grass silage by near infrared reflectance spectroscopy. Anim. Feed Sci. Technol. 115: 295311. 